\title{
Characterisation of clay mineralogy of the major soils in the Northern region of Sri Lanka
}

\author{
P Gowthamy $^{1}$, SP Indraratne ${ }^{2}$, R Weerasooriya ${ }^{3}$ and RB Mapa $^{1^{*}}$ \\ ${ }^{I}$ Department of Soil Science, Faculty of Agriculture, University of Peradeniya, Peradeniya. \\ ${ }^{2}$ Department of Environmental Studies and Sciences, University of Winnipeg, Canada. \\ ${ }^{3}$ National Institute of Fundamental Studies, Hanthana, Kandy.
}

Submitted: 28 September 2020; Revised: 07 January 2021;Accepted: 28 February 2021

\begin{abstract}
Clay content and mineralogy affect the behaviour of soils by influencing many soil properties. The soils of Sri Lanka were classified into 23 great soil groups (GSG) in 1972 and presently reclassified according to the international methods of soil taxonomy. Recently, the GSGs of latosols, namely, calcic red latosols, calcic yellow latosols (CRL and CYL), red latosols and yellow latosols (RL and YL) from the Northern region of Sri Lanka were classified under entisol soil order of soil taxonomy in contrast to earlier classification of oxisol soil order. Therefore, the objectives of this study were to characterise clay mineralogy of the major soil series in the Northern region of Sri Lanka and to confirm the soil classification of latosols. Soil samples from nine soil series were collected and analysed for clay mineralogy using infra-red (IR) spectroscopy. Dominated clay minerals were montmorillonite $(70 \%)$ and kaolinite $(20 \%)$ for vertisol soil order, kaolinite (50-70\%) and montmorillonite (40-20\%) for alfisol soil order and kaolinite (80-90\%) for entisol soil order. All soils have shown evidence for the presence of quartz and feldspar. Latosol GSG showed distinctive IR peaks at $3695 \mathrm{~cm}^{-1}, 3670 \mathrm{~cm}^{-1}, 3650 \mathrm{~cm}^{-1}$, and $3620 \mathrm{~cm}^{-1}$ representing well-crystallised kaolinite with no evidence for oxide minerals. Latosols did not have mineralogical signatures to classify under oxisols. Mineralogical composition of soil orders of alfisols and vertisols was confirmed with their respective classification. Clay mineralogical information confirmed that latosol GSG could be classified under entisol order though the latosols are at an advanced stage of soil development.
\end{abstract}

Keywords: Clay minerals, infra-red spectroscopy, latosols, oxisols.

\section{INTRODUCTION}

Clay content and mineralogy plays a vital role in governing soil properties in agricultural and engineering applications. Clay particles $(<2 \mu \mathrm{m})$, being the finest mineral particles found in soils offer the highest specific surface influencing soil behaviour due to retention of nutrients and water. Clay particles constitutes variety of minerals, namely, micas (illites), vermiculites, smectites (montmorillonites), kaolins (kaolinites), chlorite and other interlayer minerals that differ widely in structure and composition (Ito \& Wagai, 2017). In addition to amount of clay, the clay mineralogy mediates many biological and physical properties in soils; formation of stable aggregates (Kraemer et al., 2019), persistence of organic matter in soils (Zhao et al., 2020), soil moisture characteristic (Williams et al., 1983) and the buffering capacity of soil (Indraratne, 2006). Hence, the importance of knowing clay mineralogy in soil management is well documented. In soil classification, dominance of clay types can be used as a tool to confirm soil orders under soil taxonomy (Soil Survey Staff, 2014); oxisols soil order consists of 1:1 clay minerals (kaolinite) and $\mathrm{Fe}$ and $\mathrm{Al}$ oxyhydroxides, such as gibbsite, hematite and goethite (Schaefer et al., 2008), Vertisols soil order dominate 2:1 expandable smectite clay minerals (Pal, 2017) and alfisols soil order

*Corresponding author (maparb@yahoo.com; (iD https://:orcid.org/0000-0002-2223-2588)

This article is published under the Creative Commons CC-BY-ND License (http://creativecommons.org/licenses/by-nd/4.0/). This license permits use, distribution and reproduction, commercial and non-commercial, provided that the original work is properly cited and is not changed in anyway. 
is dominated by kaolinite and illite (Zhang et al., 2016). Soil family level informationin soil taxonomy is directly related to dominant soil mineral types (e.g., kaolinitic, smectitic, gibbsitic) and particle-size distribution (e.g., clayey, loamy, sandy) (Soil Survey Staff, 2014).Soils of Sri Lanka were classified in 1972 into 23 great soil groups (GSG) by de Alwis and Panabokke (1972). With the global advancement of soil science, a need arisen to classify the soils of Sri Lanka according to the international methods of soil taxonomy and to develop a national soil database (Mapa, 2020).

Clay mineralogy of Sri Lankan soils has been studied by many researchers (Panabokke, 1958; Kalpage et al., 1963; De Alwis \& Pluth, 1976; Indraratne 2006;), mostly using $\mathrm{x}$-ray diffraction technique covering major rainfall zones (wet, intermediate and dry zones). In general, wet zone consists of kaolinite, illite, gibbsite, hydroxy-interlayered vermiculite, and traces of boehmit; intermediate zone consists of kaolinite, smectites, vermiculites, and mica; dry zone consists of kaolinite, smectite, vermiculite, and mica (Indraratne, 2020). Most of these studies did not include soils of the Northern region of Sri Lanka. De Alwis and Panabokke (1972) identified nine GSG in the Northern region consisting of calcic red latosols (CRL), calcic yellow latosols (CYL), red latosols (RL), yellow latosols (YL), grumusols, solodized solonetz (SS), reddish brown earth soils (RBE), low humic gley soils (LHG), and sandy regosols (SR). According to the latest soil classification of soil taxonomy (Mapa et al., 2010), these GSGs belong to entisols (CRL, CYL, RL, YL and SR), alfisols (RBE, LHG, and SS) and vertisols (Grumusols) soil orders. In an earlier classification, latosols in the Northern region (CRL, CYL, RL, and YL) were classified under oxisols (de Alwis \& Panabokke, 1972). Though the other GSG are found elsewhere in Sri Lanka, latosols are unique only to the Northern region of the country. Miocene limestone of Sri Lanka lying on the Precambrian basement of the North, Northern and South-western coastal belts (Cooray, 1984; Katupotha \& Dias, 2001) is the parent materials mainly responsible for the development of soils in the region. The latosols are developed on transported material that overlies Miocene limestone and mainly occurs in the Jaffna Peninsular (Panabokke, 1996; Chandrajith, 2020). Hence, there is a controversy in classifying latosols according to soil taxonomy; De Alwis and Panabokke (1972) placed them under oxisols while Mapa et al. (2010), placed them under entisols. Deeply weathered soils with no distinct horizon boundaries occurring in dense rainfall areas are classified as latosols in many parts of the world (Ruivo $\&$ Cunha 2003). In latosols the soil profile is uniform in chemical and mineral composition, kaoline making up $>50 \%$ of the clay fraction together with iron oxides and gibbsites (Sherman \& Alexander, 1959). Most of these latosols reported globally were classified under oxisols in Soil Taxonomy (Schaefer et al., 2008). Therefore, clay mineralogical analysis of latosols of the Northern region will provide sufficient information to a certain degree to solve this controversy on soil classification.

Fourier transform infrared (FTIR) spectroscopy provide valuable information on mineralogical composition as each mineral has a unique absorption pattern in the mid-IR range (Hahn et al., 2018). Clay mineral units generally constitute hydroxyl groups, tetrahedral silicate/aluminate anions, octahedral metal cations, and interlayer cations. FTIR-spectral signatures of minerals enable to identify individual minerals as well as non-crystalline admixtures using unique absorption patterns (Vaculicova \& Plevova, 2005). IR spectra of clay minerals are usually characterise by three main areas: (i) the stretching and bending vibrations of the inner surface $-\mathrm{OH}$ groups observed in the region of 3700 to $3600 \mathrm{~cm}^{-1}$, (ii) the stretching and bending vibrations of the $\mathrm{Si}-\mathrm{O}$ groups, and (iii) the $\mathrm{Si}-\mathrm{O}-\mathrm{M}$ (with $\mathrm{M}=\mathrm{Al}, \mathrm{Mg}$, etc.) vibrations extending from 1200 to $400 \mathrm{~cm}^{-1}$ (Müller et al., 2014).

The technical difficulty in quantifying clay-sized minerals is a well-known fact (Środoń, 2013), which leads to limited published soil datasets, globally (Ito \& Wagai, 2017). Soil mineralogical characterisation has not been done to date for the soils in Northern region of Sri Lanka. The peculiar climatic and geological characteristics of the Northern region offer a unique opportunity to unravel the provenance of clay types in the region. Identifying the mineralogical composition of the soils of the Northern region is essential in terms of filling a knowledge gap on soil mineralogy which could be used for planning agricultural and engineering applications. Therefore, we characterised the clays and other minerals in major soils in the Northern region using Fourier transform infrared spectroscopy (FTIR). The FTIR spectra provide spectral signatures that can be unequivocally used to identify different minerals in soils. We hypothesised that the presence of $\mathrm{Fe}$ and $\mathrm{Al}$ hydroxides together with well-crystallised kaolinite in latosols would give an insight to confirm latosols under oxisols.

\section{METHODOLOGY}

\section{Study location and collection of soils}

Soils of the Northern part of Sri Lanka were collected from pre-identified benchmark sites representing major soil series (Mapa, 2016) during 2013 and 2014 covering two agro-ecological regions (DL3 and DL4) in lowcountry dry zone. The major series of soil of Northern 
region were identified based on soil, topography, parent material, climate, vegetation and previous information with the assistance of the Land Use Division of the Irrigation Department of Sri Lanka. Out of 12 recently geo-referenced benchmark soil profiles of Northern region of Sri Lanka (Mapa, 2016), nine different major soil series were selected for mineralogical analysis (Figure 1). Details of identified benchmark soil profiles and their locations were described elsewhere (Vitharana et al., 2019). The soil series names, GSG names according to classification in 1972 (De Alwis \& Panabokke, 1972) and their Soil Taxonomic equivalents (Soil Survey Staff, 2014) to sub-group level are given in Table 1. These include GSGs of CRL, CYL, SS and SR from Jaffna, RBE and LHG from Vavuniya, RL and YL from Vishwamadu, and grumusols from Mannar. The exact location / benchmark site for each soil series was recorded using GPS (Figure 1, Table 1). A soil pit was dug to a depth of $1 \mathrm{~m}$ or until hit by the parent rock at each location. Composite soil samples collected from the surface horizon (0-30 cm depth) of benchmark sites were subjected to the separation of clay fraction and mineralogical analysis.

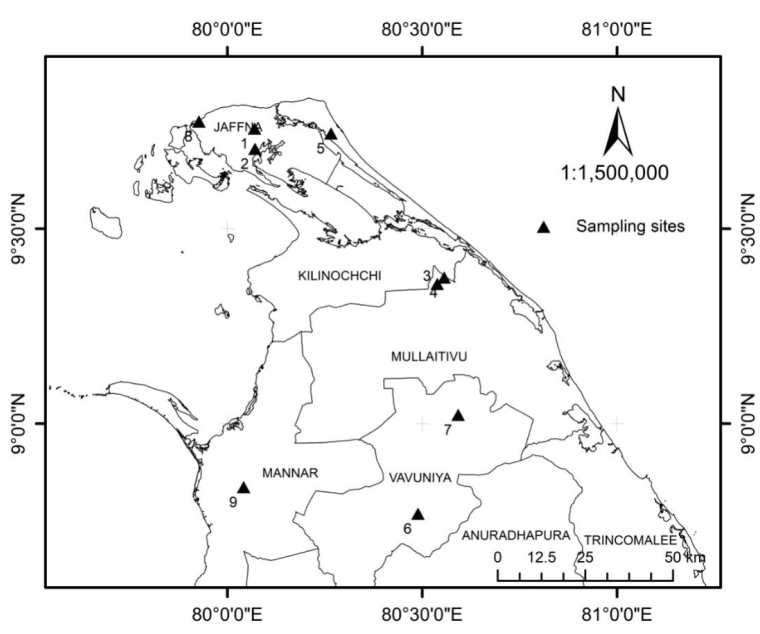

Figure 1: Sampling locations for clay mineralogy analysis of the study

Table 1: The sample locations, great soil groups, soil series names and equivalent soil taxonomic names of soils of the Northern region of Sri Lanka

\begin{tabular}{|c|c|c|c|c|}
\hline Sample location & Soil series & Great soil group* & Abbreviation & Soil taxonomy \\
\hline $\begin{array}{l}\text { Lat : } 09045^{\prime} 25.5 " \mathrm{~N} \text {, } \\
\text { Lon: } 080004^{\prime} 11.4 ” \mathrm{E}\end{array}$ & Inuvil & Calcic red latosols & CRL & Typic Ustorthents \\
\hline $\begin{array}{l}\text { Lat : } 09042{ }^{\prime} 18.3{ }^{\prime \prime} \mathrm{N}, \\
\text { Lon: } 080004{ }^{\prime} 15.6 ” \mathrm{E}\end{array}$ & Chankanai & $\begin{array}{l}\text { Calcic yellow } \\
\text { Latosols }\end{array}$ & CYL & Aquic Ustorthents \\
\hline $\begin{array}{l}\text { Lat : } 090211^{\prime} 31.6 " \mathrm{~N} \text {, } \\
\text { Lon: } 080032 \text { ' 19.1" E }\end{array}$ & Mulathivu & Red latosols & RL & Typic Ustorthents \\
\hline $\begin{array}{l}\text { Lat : } 09022^{\prime} 30^{\prime \prime} \mathrm{N} \text {, } \\
\text { Lon: } 080033^{\prime} 22.6^{\prime \prime} \mathrm{E}\end{array}$ & Thanniyuttu & Yellow latosols & YL & Oxyaquic Ustorthents \\
\hline $\begin{array}{l}\text { Lat : } 09044^{\prime} 40.1 " \mathrm{~N} \text {, } \\
\text { Lon: } 080015^{\prime} 57.4 ” \mathrm{E}\end{array}$ & Colombatharaj & Sandy regosol & SR & $\begin{array}{c}\text { Aquic } \\
\text { Quartzipsamments }\end{array}$ \\
\hline $\begin{array}{l}\text { Lat: } 080466^{\prime} 8.90 " \mathrm{~N} \text {, } \\
\text { Lon: } 080029^{\prime} 21.11^{\prime} \mathrm{E}\end{array}$ & Vavunia & Low humic gley & LHG & Typic Endoaqualfs \\
\hline $\begin{array}{l}\text { Lat : } 09001 ' 22.30 " \mathrm{~N} \text {, } \\
\text { Lon: } 080035^{\prime} 32.34 ” \mathrm{E}\end{array}$ & Nadunkanei & Reddish brown earth & RBE & Typic Rhodustalfs \\
\hline $\begin{array}{l}\text { Lat : } 090466^{\prime} 29.4 ” \mathrm{~N} \text {, } \\
\text { Lon: } 079055^{\prime} 37.3 ” \mathrm{E}\end{array}$ & Tondaimanar & Soladized solonetz & SS & Albic Natraqualfs \\
\hline $\begin{array}{l}\text { Lat: } 080500^{\prime} 14.1{ }^{\prime} \mathrm{N} \text {, } \\
\text { Lon: } 0800022^{\prime} 30.1 ” \mathrm{E}\end{array}$ & Murunkkan & Grumusols & Grumusols & Aridic Endoaquerts \\
\hline
\end{tabular}

*source de Alwis \& Panabokke, 1972; Lat=latitude;=Lonlongitude 
Separation of clay fraction and mineralogical analysis

Soil samples were washed with distilled water to remove soluble salts and treated with $30 \% \mathrm{H}_{2} \mathrm{O}_{2}$ for organic matter removal and sodium citrate-bicarbonate-dithionite at $80{ }^{\circ} \mathrm{C}$ for iron oxide removal before separation of the clay fraction $(<2 \mu \mathrm{m})$.

Clay fraction was separated by sedimentation under gravity according to Stoke's Law (Gee \& Or, 2002). Clay samples were air-dried, and soil mineralogy was characterised using infrared spectrometry (IR) (White \& Roth, 1986). We used IR spectrums of kaolinite, illite feldspar, and quartz reported by Djomgoue and Njopwouo (2013), Hanhn et al. (2018) and Müller et al. (2014) to interpret data. These were selected as the probable minerals present in the dry zone soil, based on our prior knowledge of types of clay and other minerals of Sri Lanka (Indraratne, 2020).

\section{FT-IR spectroscopic studies}

For the FT-IR studies, all spectra were acquired with a Thermo Nicolet Magna FTIR Si 50 (Madison, WI) with a DTGS KBr detector at the Department of Soil Science, University of Peradeniya. The wavenumber range was 4000 to $400 \mathrm{~cm}^{-1}$, and each spectrum consisted of 64 scans; the resolution was $4 \mathrm{~cm}^{-1}$, and wavenumber accuracy was $1 \mathrm{~cm}^{-1}$. About $20 \mathrm{mg}$ of finely ground soil samples were mixed with $12 \mathrm{mg}$ IR grade $\mathrm{KBr}$ and pressed into a 3-mm-diameter pellet using paper inserts (Spectra-Tech, Shelton, CT). Clay IR spectra were compared against standard kaolinite, montmorillonite, illite, quartz and feldspar spectra to attest their signatures.

\section{RESULTS AND DISCUSSION}

\section{Qualitative analysis of clay minerals}

The IR spectrum of kaolinite is readily identifiable and definable over other clay minerals due to a unique pattern in the spectral region of the inner surface $-\mathrm{OH}$ vibrations. Kaolinite shows four clear distinctive peaks at $3695 \mathrm{~cm}^{-1}, 3670 \mathrm{~cm}^{-1}, 3650 \mathrm{~cm}^{-1}$, and $3620 \mathrm{~cm}^{-1}$, which are attributed to the inner phase and outer phase motion modes, and the stretching vibration of inner surface $-\mathrm{OH}$ groups (Balan et al., 2005). Out of the four well resolved $(-\mathrm{OH})$ bands in the IR spectrum of kaolinite, the fourth band $\left(3620 \mathrm{~cm}^{-1}\right)$ is attributed to the vibrations of inner hydroxyl groups (Dijomgoue \& Njopwouo, 2013). The IR spectra of reddish brown earth (RBE) and low humic gley (LHG) showed four distinct peaks due to kaolinite at $3695 \mathrm{~cm}^{-1}, 3670 \mathrm{~cm}^{-1}, 3650 \mathrm{~cm}^{-1}$, and $3620 \mathrm{~cm}^{-1}$. In FTIR of RBE showed a clear, distinct, and equal intensity peaks at $3695 \mathrm{~cm}^{-1}$ and $3620 \mathrm{~cm}^{-1}$, whereas LHG showed two sharp peaks but with a stronger peak at $3620 \mathrm{~cm}^{-1}$ than at $3695 \mathrm{~cm}^{-1}$ (Figure 2). The characteristic vibration peaks for smectite $\left(\mathrm{O}-\mathrm{H}\right.$ stretching) were at $3628 \mathrm{~cm}^{-1}$ (Madejová, 2003). Generally, the $3620 \mathrm{~cm}^{-1}$ stretching mode can be presented in both kaolinite and 2:1 clay mineral [dioctahedral illite and (or) illite-vermiculite] (Szymański et al., 2014). When the bond stretching intensity of $3620 \mathrm{~cm}^{-1}$ was stronger than that of $3695 \mathrm{~cm}^{-1}$, that indicated the presence of a large amounts of 2:1 type clay mineral (Zhang et al., 2016). LHG showed a stronger peak at $3620 \mathrm{~cm}^{-1}$ than at $3695 \mathrm{~cm}^{-1}$ indicating that LHG constitutes higher montmorillonite and lower kaolinite than RBE. Broad peaks can observe represented water-absorption bands in the region (2800-3700 $\mathrm{cm}^{-1}$ ) of smectite, illite and chlorite (Hahn et al., 2018; Madejová, 2003). Wavelength peaks at 3624 $\mathrm{cm}^{-1}$ (Al-OH) and $3422 \mathrm{~cm}^{-1}$ (Water) can be attributed to montmorillonite (Long et al., 2013). Water-absorption peaks at $3422 \mathrm{~cm}^{-1}$ in both RBE and LHG indicates the presence of montmorillonite, but the sharpness of the peak is greater in LHG than in RBE. Hydrated phyllosilicates (e.g. chlorite, illite, smectite) show peaks around $1630 \mathrm{~cm}^{-1}$, related to the $\mathrm{H}-\mathrm{O}-\mathrm{H}$ bonds of absorbed water (Angaji et al., 2013). These peaks, however, are not diagnostic features of specific clay minerals, but indicative of the presence of water-absorbed minerals like montmorillonite. A peak was observed at $1620 \mathrm{~cm}^{-1}$ in both RBE and LHG, and the LHG peak is stronger than the RBE. Illite and montmorillonite have similar spectra, except a medium spectral bending vibration peak of $\mathrm{OH}$ group at $1635 \mathrm{~cm}^{-1}$ and a weak shoulder peak at $885 \mathrm{~cm}^{-1}$ attributed to the $\mathrm{Fe}-\mathrm{Al}-\mathrm{OH}$ vibration, which is unique only to montmorillonite (Müller et al., 2014). The changes in the structures of kaolinite and 2:1 type clay minerals (illites and smectites) also occurred in the range of 1200 - $400 \mathrm{~cm}^{-1}$ (Zhang et al., 2016). Well-crystalline kaolinite would present four groups of dual vibration modes near 1100-1120, 1000-1040, 910-940 and 753$795 \mathrm{~cm}^{-1}$, which were assigned to Si-O bands (Madejová, 2003). All these peaks in the range of $1200-400 \mathrm{~cm}^{-1}$ are visible in $\mathrm{RBE}$ and $\mathrm{LHG}$, where RBE showed more clear and distinct peaks than LHG. Furthermore, a shoulder peak arising from the Al-OH-Al bending vibration is evident at $915 \mathrm{~cm}^{-1}$ for illite, montmorillonite and kaolinite (Srasra et al., 1994). We conclude that alfisols consisted of kaolinite and montmorillonite (and may also be with illite) as clay minerals. The sharpness and prominence of the peaks revealed that the LHG is having an equal amounts of kaolinite and montmorillonite, where as RBE is predominating with kaolinite. The major absorption features of quartz are the peaks in between 
1200 to $900 \mathrm{~cm}^{-1}$ assigned to the asymmetric stretching vibrations of the $\mathrm{Si}-\mathrm{O}$ groups with a peak maximum at $1080 \mathrm{~cm}^{-1}$, the symmetric stretch at $800 \mathrm{~cm}^{-1}$ and 780 $\mathrm{cm}^{-1}$, and the symmetric and asymmetric Si-O bending modes at 695, 520, and $450 \mathrm{~cm}^{-1}$, respectively (Müller et al., 2014; Saikia et al., 2008). RBE and LHG showed peaks at $1002 \mathrm{~cm}^{-1}, 800 \mathrm{~cm}^{-1}, 780 \mathrm{~cm}^{-1}, 695 \mathrm{~cm}^{-1}$

and $520 \mathrm{~cm}^{-1}$, confirming presence of quartz. The IR spectrum of SS, which is a saline soil, was very complicated and undefined probably due to interferences from other minerals or free ions and oxides in the soil. We could not predict the presence of clay minerals, because there were no clear identifiable peaks for kaolinite, montmorillonite or illite in the absorption spectra in SS. At the same time, in SS, there was a prominent peak at $1742 \mathrm{~cm}^{-1}$, which was non-definable in terms of major clay minerals.
The carbonates have the fundamental vibrations due to $\left(\mathrm{CO}_{3}\right)_{2}$ - ion assigned to the asymmetric stretch at 1400 $\mathrm{cm}^{-1}$ and the outer plane bending vibration at $875 \mathrm{~cm}^{-1}$ (Chester \& Elderfield, 1967). There was a broad peak at $1400 \mathrm{~cm}^{-1}$ and unidentifiable peaks at $875 \mathrm{~cm}^{-1}, 727 \mathrm{~cm}^{-1}$ and $712 \mathrm{~cm}^{-1}$ in the spectra of SS signifying the probable presence of calcite. Hence, out of the three alfisols, RBE and LHG consisted of kaolinite, montmorillonite (illite) and quartz, LHG having higher montmorillonite than RBE. SS showed no strong evidence for clay minerals due to broad peaks. The smectite, illite and kaolinite were the dominant clay minerals present in alfisols found in many parts of the dry zone of Sri Lanka (Indraratne, 2010). Clay mineralogy of RBE and LHG collected from North Central Province of Sri Lanka also reported kaolinite as the dominant and smectite (montmorillonite)

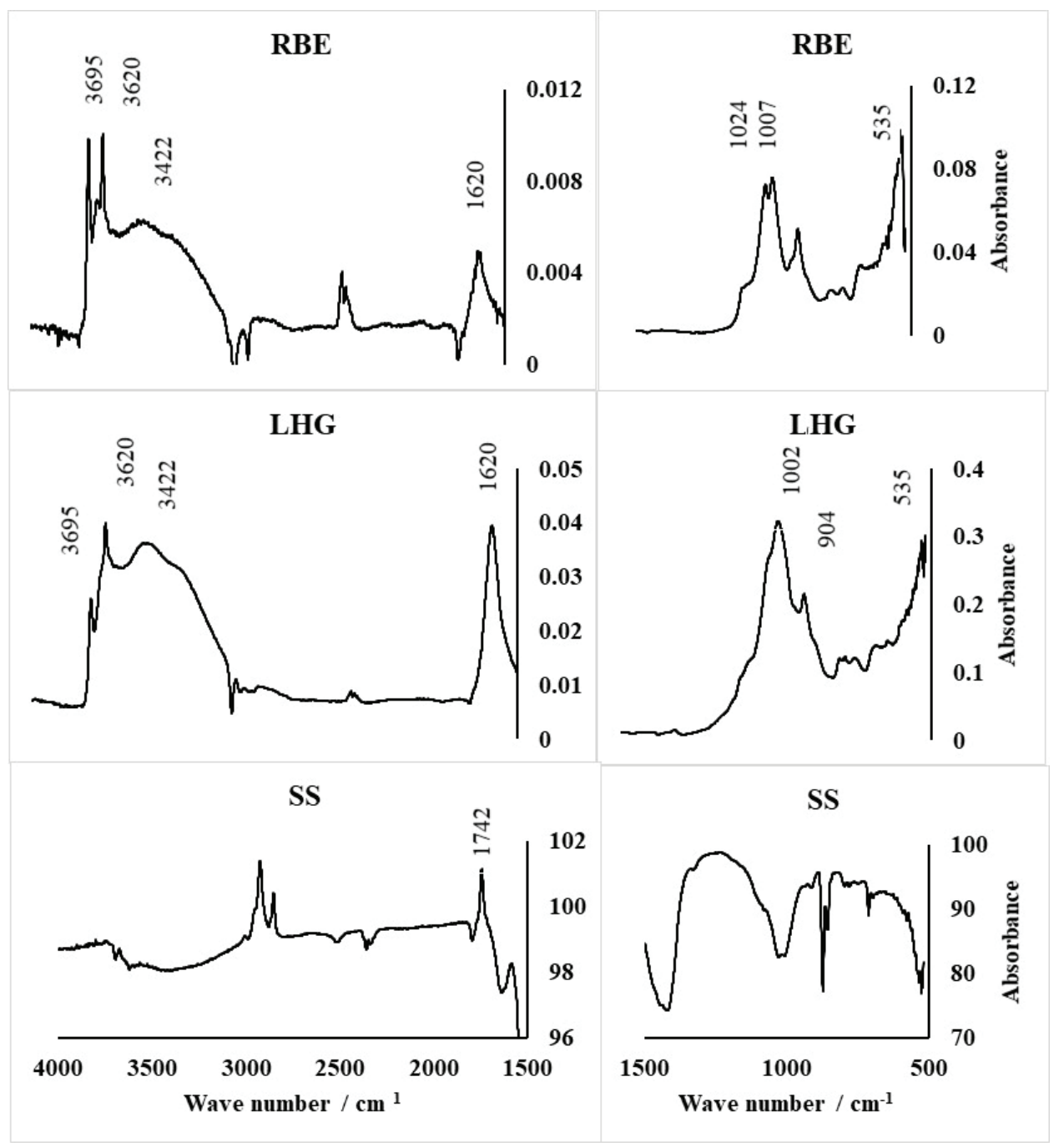

Figure 2: Infrared spectra for the wave number range 4000 to $400 \mathrm{~cm}^{-1}$ for clay fraction of great soil group of reddish brown earth (RBE), low humic gley (LHG) and solodized solonetz (SS) classified under alfisol order 
as the accessory minerals (Kalpage et al., 1963 Mapa 1992: ). Clay mineralogical changes have been reported for RBE and LHG where RBE at a well-drained crest position showed a greater level of kaolinite in clay fraction, while LHG in the poorly drained valley showed significant amount of montmorillonite clay (Panabokke, 1958 Mapa, 1992;). SS collected from DL1a agro-ecological zone of Sri Lanka (dry zone), previously indicated clay mineralogy of $50 \%$ kaolinite, $20 \%$ montmorillonite and $30 \%$ illite (Indraratne, 2020). Kaolinite and montmorillonite were present in the grumusols as indicated by the peaks at $3695 \mathrm{~cm}^{-1}$ and $3620 \mathrm{~cm}^{-1}$, and the latter is stronger than the former peak (Figure 3). The clay fraction of the grumusols had obvious and distinct peaks at $3422 \mathrm{~cm}^{-1}$ and $1635 \mathrm{~cm}^{-1}$ (Figure 3), related to the H-O-H bonds of absorbed water, confirming the dominance of montmorillonite clay mineral. Grumusols showed a broad distinctive peak in the range of $1200 \mathrm{~cm}^{-1}$ to $840 \mathrm{~cm}^{-1}$, indicating the presence of kaolinite, montmorillonite and quartz mixture. There were no distinctive kaolinite peaks present as in RBE, and the dominance of montmorillonite is quite visible in grumusols. Grumusols classified into vertisols had montmorillonite as the dominant clay mineral and kaolinite as the accessory mineral. In a previous study, a grumusols belonged to vertisols, showed $20-30 \%$ of kaolinite and $70-80 \%$ of montmorillonite and vermiculite in the clay composition (Indraratne, 2020).

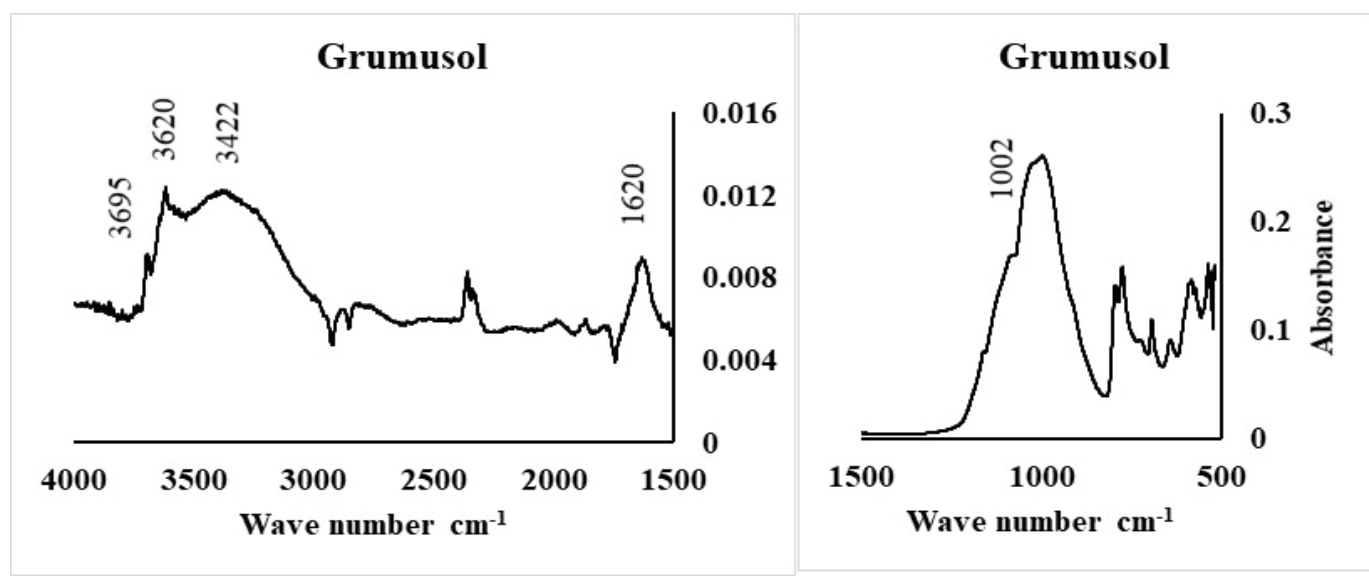

Figure 3:. Infrared spectra for the wave number range 4000 to $400 \mathrm{~cm}^{-1}$ for clay fraction of great soil group of grumusols classified to vertisol order

Sandy regosols (SR), classified under entisols had distinct, clear peaks for kaolinite at $3695 \mathrm{~cm}^{-1}$, and $3620 \mathrm{~cm}^{-1}$ (Figure 4) with the indication of the presence of both kaolinite and montmorillonite as discussed before. Montmorillonite signatures in SR were not strong as in grumusols, LHG or RBE, indicating the presence of trace amounts. Peaks present in between 1200 and $900 \mathrm{~cm}^{-1}$, with a very clear peak at $1002 \mathrm{~cm}^{-1}$, signified the presence of quartz, and four distinctive peaks in the region of $1100 \mathrm{~cm}^{-1}$ to $795 \mathrm{~cm}^{-1}$ indicated the presence of well-crystallised kaolinites. Therefore, kaolinite is the dominant clay mineral in SR

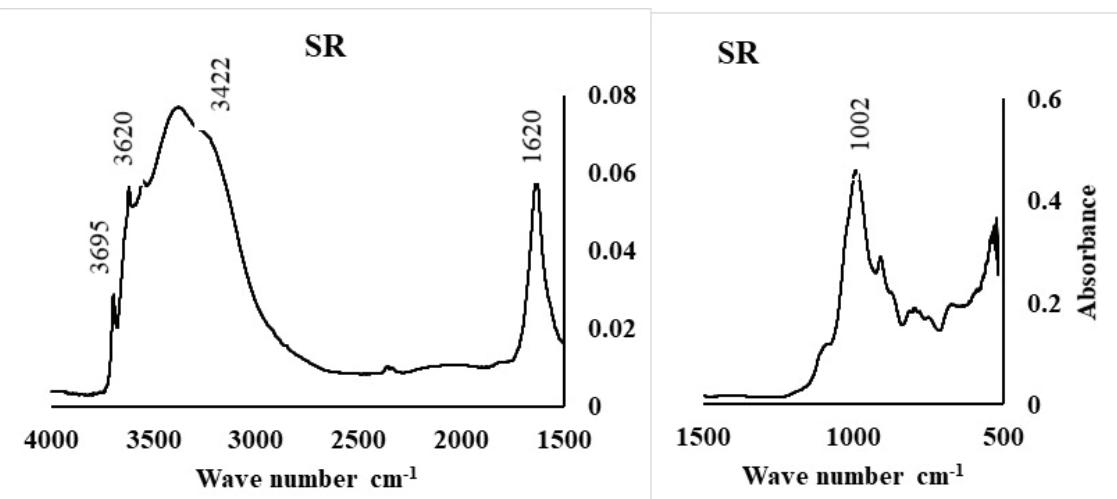

Figure 4:. Infrared spectrafor the wave number range 4000 to $400 \mathrm{~cm}^{-1}$ for clay fraction of great soil group of sandy regosols (SR) classified to entisol order 
with traces of montmorillonite. The infrared spectra of the clay minerals of CRL, CYL, RL, and YL are shown in Figure 5. All four great soil groups had distinct, clear peaks at $3695 \mathrm{~cm}^{-1}$ and $3620 \mathrm{~cm}^{-1}$, a clear indication of the presence of kaolinite clay mineral. In CYL and CRL, a stronger peak at $3620 \mathrm{~cm}^{-1}$ than at $3695 \mathrm{~cm}^{-1}$, and peak at $1620 \mathrm{~cm}^{-1}$ indicated the presence of montmorillonite as an accessory mineral. RL and YL showed similar spectral fingerprints and kaolinite as the dominant clay mineral showed equally strong, distinctive peaks at $3695 \mathrm{~cm}^{-1}$ and $3620 \mathrm{~cm}^{-1}$. A clear peak at $1002 \mathrm{~cm}^{-1}$ and the symmetric and asymmetric $\mathrm{Si}-\mathrm{O}$ bending mode at $695 \mathrm{~cm}^{-1}$ and
$520 \mathrm{~cm}^{-1}$ signify the presence of quartz mineral. The prominence of kaolinite in RL and YL further confirmed with the clear kaolinite peaks from $1100 \mathrm{~cm}^{-1}$ to $795 \mathrm{~cm}^{-1}$ range. Kaolinite is the dominant clay mineral present in these four latosols classified under entisols order. $\mathrm{X}$-ray diffraction studies confirmed that RL consists of dominantly kaolinite and traces of illite (Indraratne, 2020). IR spectra should report four strong absorption $\mathrm{OH}$-stretching bands at 3397, 3467, 3529 and $3623 \mathrm{~cm}^{-1}$ wavenumbers to confirm the presence of gibbsite (Balan et al., 2005; Favaro et al., 2010) and there were no such peaks visible for any of the soils studied.

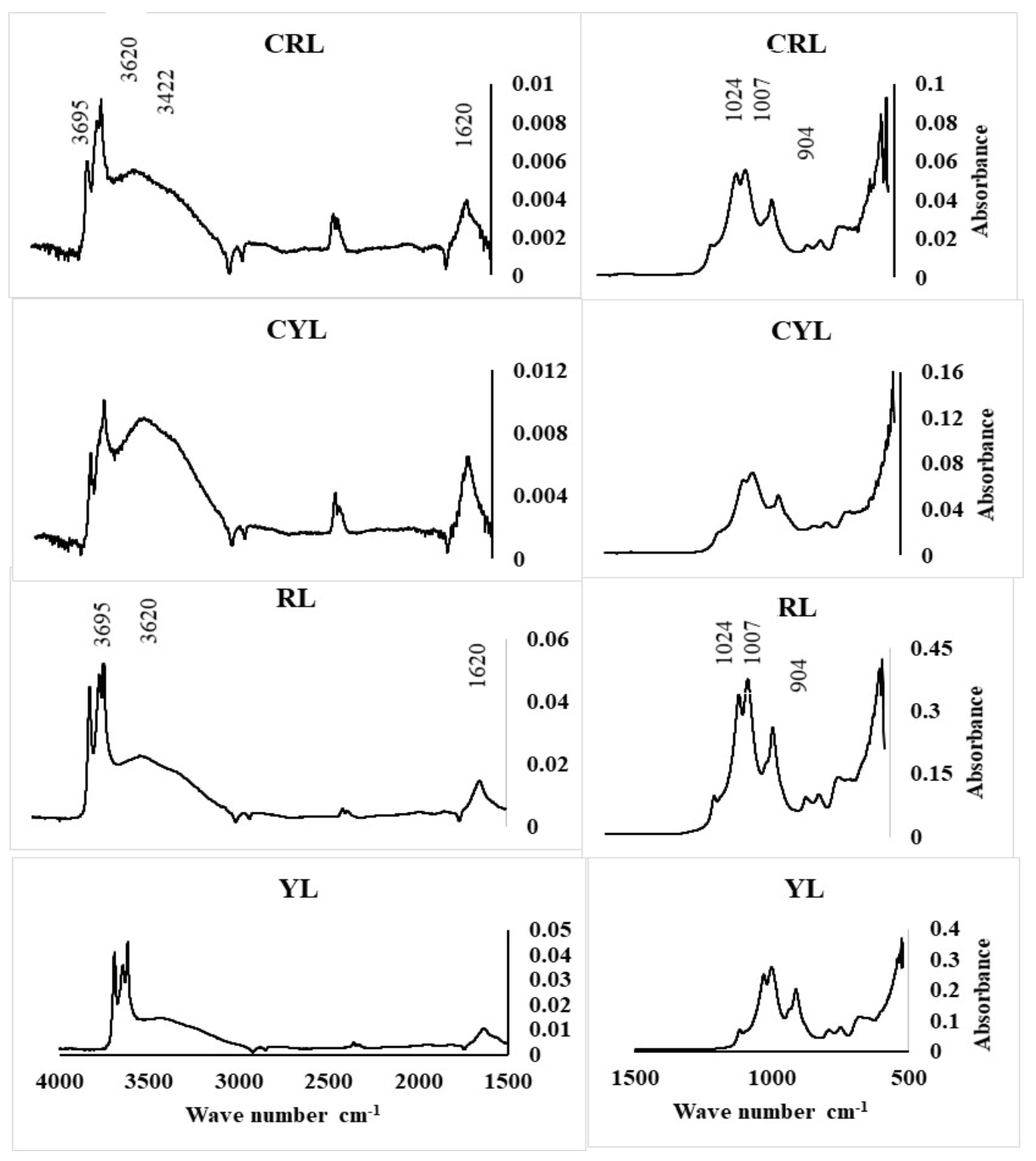

Figure 5:. Infrared spectra for the wave number range 4000 to $400 \mathrm{~cm}^{-1}$ for clay fraction of great soil groups of calcic red latosol (CRL), calcic yellow latosol (CYL), red latosol (RL) and yellow latosol (YL) classified under entisol order 
The kaolinite group with 1:1 type layer structure is predominant in the humid tropics, and the illite/mica group is abundant in arid and high-latitude regions (Ito \& Wagai, 2017). Kaolinite, smectite, vermiculite, and mica were the mineralogical make-up for dry zone soils of Sri Lanka (Indraratne, 2020). RBE and LHG consisted of kaolinite, montmorillonite and quartz confirming mineralogical signature for Alfisols. Vertisols contain a high proportion of smectite in the topsoil, which are known to have localised distributions in the tropics (Ito \& Wagai, 2017). Grumusols classified under vertisols had montmorillonite as the dominant clay mineral and kaolinite as the accessory mineral. Well-crystallised kaolinite was the dominant clay mineral in SR, CYL, CRL, RL and YL classified under entisols order.

\section{Clay mineralogy to predict relative development stages of great soil groups}

Using IR spectra of clay minerals given in Figures 2-5 for the soils of the Northern region of Sri Lanka (except for SS), the relative abundance was estimated by sharpness and prominence of peaks for kaolinite and montmorillonite (Table 2). Relative abundance of clay minerals for SS was derived from the work of Indraratne (2010) in order to compare it with other soils. Kaolinite was the dominant clay mineral in all soils except grumusols. Soils can be arranged according to the dominance (sharpness of the peak) of kaolinite among soils in ascending order as grumusols $<\mathrm{LHG}<\mathrm{RBE}<$ $\mathrm{CRL}<\mathrm{CYL}<\mathrm{SR}<\mathrm{RL}$, YL. Montmorillonite content of the soil is varied among soils from very high (grumusols) to trace amounts (RL, YL, and SR). Clear and distinct montmorillonite peaks was observed in grumusols LHG and RBE. Weak montmorillonite signatures were observed in CYL, CRL SR and RL and YL with trace amounts. According to the sharpness and dominance of frequency, peaks of montmorillonite soils could be arranged in ascending order as grumusols $>>$ LHG $>>$ $\mathrm{RBE}>>\mathrm{CYL}, \mathrm{CRL}>\mathrm{SR}>\mathrm{RL}, \mathrm{YL}$. The LHG occurred in a poorly drained (aqualfs) part of the catena compared to RBE, showed a high content of montmorillonite clays than in the RBE, which is a well-drained (ustalfs) soil. The reason for this difference is the lower weathering rates experienced in poorly drained conditions which affect the mineralogy even if the soils are formed from the same parent martial.

Generally, evolutionary sequence of clay minerals is in the order primary weatherable minerals (biotite, muscovite, feldpar) illite smectite (and or vermiculite) kaolinite (Djomgoue \& Njopwouo, 2013). Weerasuriya et al (1991) predicted weathering stage of Sri Lankan soils using geochemical characteristics such as residual primary minerals, secondary clay minerals and silica content. The relative abundance of phyllosilicates, one of the indices of weathering intensity, can be used to predict the relative weathering stage of studied soils (Table 2). Grumusols, the vertisolic soil, qualified as the youngest soil among the studied soils due to the presence of $70 \% 2: 1$ montmorillonite clays. Alfisols soils, SS, RBE and LHG, were the second youngest soil, LHG being younger than SS and RBE due to presence of a higher proportion of montmorillonite. When compared with alfisols in the Northern region (RBE, LHG), order entisols (CRL, CYL, RL, YL and SR) had low to traces of montmorillonites, and high proportions ( $>80 \%$ ) of kaolinite indicating these entisols are at an advanced stage of weathering compared to other soil orders. There was a limited information on mineralogy of latosolic soils in Sri Lanka. According to this study, kaolinite is the dominant clay mineral with or without traces of montmorillonite in latosols. With the help of the clay mineralogy, soils of the Northern region can be arranged from young to mature; grumusols $<\mathrm{LHG}<\mathrm{RBE}$, SS $<<$ CYL, CRL $<$ SR $<$ RL, YL. Distinct variability of clay mineral proportions can be observed in some soil orders; in alfisols, kaolinite $>$ illite/mica > smectite / vermiculite, in vertisols, smectite / vermiculite $>>$ kaolinite, in entisols, illite/mica $>$ smectite / vermiculite $>$ kaolinite, and in oxisols, kaolinite $>$ gibbsite $>$ Fe-oxides (Ito and Wagai 2017). According to the mineralogical composition alfisols (RBE, SS and LHG) and vertisols (Grumusols) confirmed their respective classification. Latosolic soils do not fall under oxisols, due to absence of oxide minerals. Advanced weathering stage of latosols indicates that these soils are fallen under entisols because of lack of diagnostic horizons, but not necessarily they are young at soil development.

Table 2: Estimate of relative abundance of clay minerals (\%) in the soils of the northern region

\begin{tabular}{lccccccccc}
\hline & \multicolumn{1}{c}{ Great soil group } \\
Clay mineral & Grumusol & LHG & SS* & RBE & CYL & CRL & RL & YL & SR \\
\hline Kaolinite & 20 & 50 & 50 & 70 & 80 & 80 & 90 & 90 & 80 \\
Montmorillonite & 70 & 40 & 20 & 20 & 10 & 10 & 0 & 0 & 10 \\
Other clay-size minerals & 10 & 10 & 30 & 10 & 10 & 10 & 10 & 10 & 10 \\
\hline
\end{tabular}

*source (Indraratne, 2020). low humic gley soils (LHG), solodized solonetz (SS), reddish brown earth soils (RBE), calcic yellow latosols (CYL), Calcic red latosols (CRL), red latosols (RL), yellow latosols (YL), and sandy regosols (SR) 


\section{CONCLUSIONS}

Great soil groups belonging to alfisols soil order (RBE, SS and LHG) confirmed mineralogical signature of kaolinite and montmorillonite as dominant clay minerals and quartz as an accessory mineral. Grumusols classified under vertisols soil order had montmorillonite as the dominant clay mineral and kaolinite as the accessory mineral. Well-crystallised kaolinite is the dominant clay mineral in SR. Kaolinite is the dominant clay mineral present in CYL, CRL, RL and YL classified under entisols order. With the help of the clay mineralogy analysis, soils of the Northern region can be arranged from young to mature; grumusols $<\mathrm{LHG}, \mathrm{SS}<\mathrm{RBE}$ $<<\mathrm{CYL}, \mathrm{CRL}<\mathrm{SR}<\mathrm{RL}, \mathrm{YL}$. The absence of oxide clay minerals in CYL, CRL, RL and YL indicates that these latosols cannot be justified classify under oxisols soil order and reclassified under entisol order.

\section{Acknowledgements}

This work was supported by the National Research Council of Sri Lanka (NRC Grant 12-122). The assistance given by Mr. A.R. Dassanayake, specialist officer at the Land Use Division of the Irrigation Department in identifying the great soil groups of the Northern region of Sri Lanka and Dr. H.A. Kadupitiya of the Natural Resource Management Center, Department of Agriculture, Peradeniya in preparation of the sampling site map is appreciated.

\section{Conflicts of interest}

The authors declare that there is no conflict of interest regarding the publication of this article.

\section{REFERENCES}

Angaji M.T., Zinali A.Z. \& Qazvini N.T. (2013). Study of physical, chemical and morphological alterations of smectite clay upon activation and functionalization via the acid treatment. World Journal of Nano Science and Engineering 03(4): 8.

DOI: https://doi.org/10.4236/wjnse.2013.34019

Balan E., Lazzeri M., Saitta A.M., Allard T., Fuchs Y. \& Mauri F. (2005). First-principles study of $\mathrm{OH}$-stretching modes in kaolinite, dickite, and nacrite. Journal of American Mineralogist 90: 50-60.

DOI: https://doi.org/10.2138/am.2005.1675

Chester R. \& Elderfield H. (1967). The Application of InfraRed absorption spectroscopy to sheet in mixed-layer illite/ smectite from bentonites. European Journal of Mineralogy 10: $111-124$.
Chandrajith R. (2020). Geology and geomorphology. In: The Soils of Sri Lanka (ed. R.B. Mapa), pp. 23-34. Springer International, Switzerland.

DOI: https://doi.org/10.1007/978-3-030-44144-9

Cooray P.G. (1984). Geology, with special reference to the Precambrian. In: Ecology and Biogeography in Sri Lanka, pp. 1-34. Springer, Dordrecht, Germany.

DOI: https://doi.org/10.1007/978-94-009-6545-4_1

De Alwis K.A. \& Panabokke C.R. (1972). Handbook of the soils of Sri Lanka. Journal of the Soil Science Society of Sri Lanka 2: 21-52.

De Alwis K.A. \& Pluth D.J. (1976). The Red Latosols of Sri Lanka II. Mineralogy and weathering. Journal of the Soil Science Society of America 40: 920-928.

DOI:https://doi.org/10.2136/sssaj1976.03615995004000060032x

Djomgoue P. \& Njopwouo D. (2013). FT-IR spectroscopy applied for surface clays characterization. Journal of Surface Engineered Materials and Advanced Technology 3(04): 275.

DOI: http://dx.doi.org/10.4236/jsemat.2013.34037

FAO (2014). World Reference Base for Soil Resources. International Soil Classification System for Naming Soils and Creating Legends for Soil Maps. Food and Agriculture Organization, Rome, Italy.

Favaro L., Boumaza A., Roy P., Lédion, J., Sattonnay G., Brubach J.B., Huntz A.M. \& Tétot R. (2010). Experimental and $a b$ initio infrared study of $\chi$-, $\kappa$-and $\alpha$-aluminas formed from gibbsite. Journal of Solid State Chemistry 183(4): 901-908.

DOI: https://doi.org/10.1016/j.jssc.2010.02.010

Gee G.W. \& Or D. (2002). Particle Size Analysis. Methods of Soil Analysis. Part 4. Physical Methods (eds. H. Dane \& C. Topp), pp. 255-289. Soil Science Society of America, Madison, Wisconsin, USA.

Hahn A., Vogel H., Andó S., Garzanti E., Kuhn G., Lantzsch H., Schüürman C., Vogt C. \& Zabel M. (2018). Using Fourier transform infrared spectroscopy to determine mineral phases in sediments. Sedimentary Geology 375: 27-35. DOI: https://doi.org/10.1016/j.sedgeo.2018.03.010

Indarratne S.P. (2020). Soil mineralogy. In: Soils of Sri Lanka (ed. R.B. Mapa). Springer International, Switzerland. DOI: https://doi.org/10.1007/978-3-030-44144-9

Indraratne S.P. (2010). Mineralogy of the soils of Sri Lanka. In: Soils of the Dry Zone of Sri Lanka. Morphology, Characterization and Classification (eds. R.B. Mapa, S. Somasiri \& A.R. Dassanayake). Special publication No. 7, pp. 48-67. Soil Science Society of Sri Lanka, Survodaya Publishers, Colombo.

Indraratne S.P. (2006). Occurrence of organo-mineral complexes in relation to clay mineralogy of some Sri Lankan soils. Journal of the National Science Foundation of Sri Lanka 34: 29-36.

Ito A. \& Wagai R. (2017). Global distribution of claysize minerals on land surface for biogeochemical and climatological studies. Scientific data 4: 170103.

DOI: https://doi.org/10.1038/sdata.2017.103

Kalpage F.S.C.P., Mitchell B.B. \& Mitchell W.A. (1963). 
The mineralogy of some Ceylon soils. Clay Minerals Bulletin 5(30): 308-318.

DOI: https://doi.org/10.1180/claymin.1963.005.30.07

Katupotha J. \& Dias P. (2001). The geological evolution correlated to the stratigraphy of the Kalpitiya. Journal of Indian Association Sedimentologists 20: 21-37.

Kraemer F.B., Hallett P. D., Morrás H., Garibaldi L., Cosentino D., Duval M. \& Galantini J. (2019). Soil stabilisation by water repellency under no-till management for soils with contrasting mineralogy and carbon quality. Geoderma 355 : 113902.

DOI: https://doi.org/10.1016/j.geoderma.2019.113902

Long H., Wu P. \& Zhu N. (2013). Evaluation of Cs+ removal from aqueous solution by adsorption on ethylaminemodified montmorillonite, Chemical Engineering Journal 225: $237-244$

DOI: https://doi.org/10.1016/j.cej.2013.03.088

Madejová J. (2003). FTIRS techniques in clay mineral studies. Vibrational Spectroscopy 31(1): 1-10.

DOI: https://doi.org/10.1016/S0924-2031(02)00065-6

Mapa R.B. (2020). Soil research and soil mapping history. In: The Soils of Sri Lanka (ed. R.B. Mapa), pp. 1-13. Springer International. Switzerland.

DOI: https://doi.org/10.1007/978-3-030-44144-9

Mapa R.B. (2016). Characterization of Soils in the Northern Region of Sri Lanka to Develop a Soil Data Base for Land Use Planning and Environmental Applications. Final Report Submitted to National Research Council of Sri Lanka. Grant No. 12-122.

Mapa R.B., Somasiri S. \& Dassanayake A.R. (2010). Soils of the Dry Zone of Sri Lanka. Morphology, Characterization and Classification, Special publication No. 7, pp. 288. Soil Science Society of Sri Lanka, Survodaya Publishers, Colombo.

Mapa R.B. (1992). Clay mineralogy of six Sri Lankan soils. Journal of Geological Society of Sri Lanka 4: 45-47.

Müller C.M., Pejcic B., Esteban L., Delle L., Piane C., Raven M. \& Mizaikoff B. (2014). Infrared attenuated total reflectance spectroscopy: an innovative strategy for analyzing mineral components in energy relevant systems. Scientific reports $\mathbf{4}$ : 6764 .

DOI: https://doi.org/10.1038/srep06764

Pal D.K. (2017). Cracking clay soils (vertisols): pedology, mineralogy and taxonomy. In: A Treatise of Indian and Tropical Soils pp. 9-42. Springer, Germany. DOI: https://doi.org/10.1007/978-3-319-49439-5_2

Panabokke C.R. (1958). A pedology study of dry zone soils. Tropical Agriculturist 64: 151-174.

Panabokke C.R. (1996). Soils and Agro-Ecological Environments of Sri Lanka. Natural Resources Series No. 2, pp. 219. Natural Resource, Energy and Science Authority of Sri Lanka, Colombo 07.

Ruivo M.L.P. \& Cunha E.S. (2003). Mineral and organic components. In: Archaeological Black Earth and Yellow Latosol In Caxiuang, Amazon, Brazil. WIT Transactions on Ecology and the Environment, volume. 64. WIT Press, UK. DOI: https://doi.org/10.2495/ECO030342
Saikia B.J., Parthasarathy G. \& Sarmah N.C. (2008). Fourier transform infrared spectroscopic estimation of crystallinity in $\mathrm{SiO}_{2}$ based rocks. Journal of Bulletin of Materials Science 31: 775-779.

DOI: https://doi.org/10.1007/s12034-008-0123-0

Schaefer C.E.G.R., Fabris J.D. \& Ker J.C. (2008). Minerals in the clay fraction of Brazilian Latosols (Oxisols): a review. Clay Minerals 43(1): 137-154.

DOI: https://doi.org/10.1180/claymin.2008.043.1.11

Sherman G.D. \& Alexander L.T. (1959). Characteristics and genesis of low humic latosols. Soil Science Society of America Journal 23(2): 168-170.

DOI: https://doi.org/10.2136/sssaj1959.03615995002300020025x

Soil Survey Staff (2014). Keys to Soil Taxonomy, $12^{\text {th }}$ edition, pp. 372. United States Department of Agriculture, USA.

Srasra E., Bergaya F. \& Fripiat J.J. (1994). Infrared spectroscopy study of tetrahedral and octahedral substitutions in interstratified illite-smectite clay. Journal of Clays and Clay Minerals 42: 237-241.

Środoń J. (2013). Identification and quantitative analysis of clay minerals. In: Developments in Clay Science, volume 5, pp. 25-49. Elsevier, Netherlands.

DOI: https://doi.org/10.1016/B978-0-08-098259-5.00004-4

Szymański W., Skiba M., Nikorych V.A. \& Kuligiewicz A. (2014). Nature and formation of interlayer fillings in clay minerals in Albeluvisols from the Carpathian Foothills, Poland. Geoderma 235-236: 396-409.

DOI: https://doi.org/10.1016/j.geoderma.2014.08.001

Vaculikova L. \& Plevova E. (2005). Identification of clay minerals and micas in sedimentary rocks. Acta Geodynamica et Geomaterialia 2(2): 163.

Vitharana U.W.A., Mishra U. \& Mapa R.B. (2019). National soil organic carbon estimates can improve global estimates. Geoderma 337: 55-64.

DOI: https://doi.org/10.1016/j.geoderma.2018.09.005

Weerasuriya T., Nesbitt H.W. \& Fyfe W.S. (1991). Geochemical characteristics of some Sri Lankan soils. Journal of the Soil Science Society of Sri Lanka 7: 54-75

White J.L. \& Roth C.S. (1986). Infrared Spectrometry. Methods of Soil Analysis. Part I. Physical and Mineralogical Methods (ed. A. Klute) pp. 291-326. Soil Science Society of America, Madison, Wisconsin, USA.

Williams J., Prebble R.E., Williams W.T. \& Hignett C.T. (1983). The influence of texture, structure and clay mineralogy on the soil moisture characteristic. Soil Research 21(1): 15-32. DOI: https://doi.org/10.1071/SR9830015

Zhao Q. et al. (12 authors) (2020). Strong mineralogic control of soil organic matter composition in response to nutrient addition across diverse grassland sites. Science of the Total Environment 736: 137839.

DOI: https://doi.org/10.1016/j.scitotenv.2020.137839

Zhang Z.Y., Huang L., Liu F., Wang M.K., Fu Q.L. \& Zhu J. (2016). Characteristics of clay minerals in soil particles of two Alfisols in China.

Applied Clay Science 120: 51-60.

DOI: https://doi.org/10.1016/j.clay.2015.11.018 